\title{
Penerapan Model Pembelajaran Project Based Learning (PjBL) untuk Meningkatkan Keaktifan dan Hasil Belajar Siswa pada Kompetensi Dasar Membuat Jamu dan Boreh/Lulur Perawatan Badan
}

\section{Ni Ketut Yuliana Dharmayani ${ }^{1 *}$}

${ }^{1}$ SMK Negeri 2 Singaraja, Singaraja, Indonesia

\section{A R T I C L E I N F O}

Article history:

Received 14 February 2021

Received in revised form 12 March 2021

Accepted 10 April 2021 Available online 11 May 2021

Kata Kunci:

Keaktifan, Hasil Belajar

Pjbl.

Keywords:

Activeness, Learning

Outcomes, Pjbl.

\begin{abstract}
A B S T R A K
Penggunaan model pembelajaran yang kurang bervariasi menyebabkan rendahnya keaktifan dan hasil belajar siswa, sehingga diperlukan model pembelajaran yang kreatif dan inovatif. Tujuan dari dilaksanakannya penelitian ini adalah untuk menganalisis penerapan model pembelajaran PjBL untuk meningkatkan keaktifan dan hasil belajar siswa pada kompetensi dasar membuat jamu dan boreh/lulur perawatan badan kelas $\mathrm{XI}$. Penelitian ini adalah penelitian tindakan kelas. Subjek dalam penelitian ini adalah semua siswa kelas XI Tata Kecantikan 3 SMK Negeri 2 Singaraja sebanyak 33 siswa. Sedangkan objek penelitian ini adalah peningkatan keaktifan belajar dan hasil belajar membuat jamu dan boreh/lulur perawatan badan siswa. Metode pengumpulan data yang digunakan adalah pemberian instrumen penilaian kepada siswa. Instrumen yang digunakan adalah lembar observasi dan lembar penilaian hasil belajar. Analisis data yang digunakan pada penelitian ini adalah analisis deskriptif kuantitatif. Hasil penelitian ini memperoleh hasil presentase keaktifan belajar siswa sebesar $61,69 \%$ pada siklus I,
\end{abstract} sebesar $81,82 \%$ pada siklus II, dan presentase hasil belajar sebesar $79,77 \%$ pada siklus, sebesar $82,27 \%$ pada siklus II. Sehingga dapat disimpulkan bahwa penerapan model pembelajaran PjBL dapat meningkatkan keaktifan dan hasil belajar membuat jamu dan boreh/lulur perawatan badan siswa kelas XI. Implikasi penelitian ini adalah memperoleh pengalaman belajar yang berhubungan dengan keterampilan menerapkan metode ilmiah dalam pemecahan masalah dan menumbuhkan pola berfikir kritis bagi siswa.

\begin{abstract}
A B S T R A K
The use of less varied learning models causes low student activity and learning outcomes, so a creative and innovative learning model is needed. The purpose of carrying out this study was to analyze the application of the Project Based Learning (PjBL) learning model to increase student activity and learning outcomes on the basic competencies of making herbal medicine and body care scrubs for class XI. This research is a classroom action research. The subjects in this study were all students of class XI Beauty 3 SMK Negeri 2 Singaraja as many as 33 students. While the object of this research is to increase learning activeness and learning outcomes in making herbal medicine and body care scrubs for students. The data collection method used was the provision of assessment instruments to students. The instruments used were the observation sheet and the learning outcome assessment sheet. The data analysis used in this research is quantitative descriptive analysis. The results of this study obtained a percentage of student learning activeness of $61.69 \%$ in cycle $1,81.82 \%$ in cycle II, and a percentage of learning outcomes of $79.77 \%$ in cycle, of $82.27 \%$ in cycle II. So it can be concluded that the application of the project based learning (PjBL) learning model can increase the activeness and learning outcomes of making Jamu and Body Care Body Scrub for class XI students. The implication of this research is to gain learning experience related to the skills of applying scientific methods in problem solving and fostering critical thinking patterns for students.
\end{abstract}




\section{Pendahuluan}

Pendidikan dan pengajaran adalah suatu proses yang sadar tujuan. Tujuan dapat diartikan sebagai suatu usaha untuk memberikan rumusan hasil yang diharapkan siswa setelah melaksanakan pengalaman belajar (Indriyani et al., 2019; Morelent \& Syofiani, 2018; Resbiantoro, 2016). Tercapai tidaknya tujuan pengajaran salah satunya adalah terlihat dari prestasi belajar yang diraih siswa. Dengan prestasi yang tinggi, para siswa mempunyai indikasi berpengetahuan yang baik. Salah satu faktor yang mempengaruhi prestasi siswa adalah motivasi. Dengan adanya motivasi, siswa akan belajar lebih keras, ulet, tekun dan memiliki dan memiliki konsentrasi penuh dalam proses belajar pembelajaran. Dorongan motivasi dalam belajar merupakan salah satu hal yang perlu dibangkitkan dalam upaya pelaksanaan pendidikan di sekolah (Krissandi \& Rusmawan, 2015; Mulyadin, 2016; Wahyudin, 2018). Pendidikan merupakan salah satu aspek sangat penting dalam upaya peningkatan mutu sumber daya manusia yang cerdas sehingga dapat menunjang kemajuan Bangsa dan Negara di masa depan. Sebagai salah satu sektor pembangunan nasional dalam upaya mencerdaskan kehidupan bangsa, adapun visi dari pembangunan nasional yaitu ter-wujudnya sistem pendidikan sebagai pranata sosial yang kuat dan berwibawa untuk memberdayakan semua Warga Negara Indonesia menjadi manusia yang berkualitas sehingga mampu dan proaktif menjawab tantangan zaman yang selalu berubah (Amelia \& Saputra, 2017; Indriani, 2015; Kurniasari, 2017).

Upaya meningkatkan mutu pendidikan formal di Indonesia merupakan salah satu implementasi kurikulum 2013. Dalam implementasinya kurikulum 2013 merupakan proses pengembangan pembelajaran dan salah satunya adalah pola pembelajaran pasif menjadi pembelajaran aktif (pembelajaran yang membuat siswa aktif mencari dan diperkuat dengan model pembelajaran pendekatan saintifik) serta pola belajar individu menjadi belajar kelompok (Kurniaman \& Noviana, 2017; Shafa, 2014; Sugiyanto et al., 2015). Sekolah Menengah Kejuruan (SMK) sebagai pendidikan formal memiliki peran dan posisi yang strategis dalam implementasi kurikulum 2013 di Indonesia (Edriati et al., 2016; Fitriyadi, 2013; Said et al., 2019). Paling tidak ada dua alasan yang menempatkan SMK pada posisi tersebut. Pertama, SMK telah menjadi salah satu tempat untuk mencerdaskan dan pemenuhan hak-hak pendidikan bagi banyak warga negara. Kedua, SMK telah memberi kontribusi penting bagi perekonomian Indonesia melalui perannya dalam menyediakan tenaga kerja terampil bagi dunia usaha dan industri.

SMK Negeri 2 Singaraja merupakan sekolah yang mempunyai fasilitas yang cukup memadai dan input siswa yang masuk dengan kemampuan serta keterampilan yang berbeda-beda, mulai dari siswa yang memiliki kemampuan belajar rendah, sedang sampai siswa yang memiliki kemampuan belajar tinggi. Berdasarkan pada observasi di kelas XI Tata Kecantikan 3 yang berjumlah 33 siswa serta wawancara dengan guru yang juga mengajar mata pelajaran Perawatan Wajah, Badan (Body Massage) dan Waxing pada kompetensi dasar membuat jamu dan boreh/lulur perawatan badan dan beberapa siswa pada kelas tersebut, diketahui bahwa metode pembelajaran yang sering digunakan dalam kegiatan pembelajaran adalah model ceramah. Penggunaan metode ceramah dalam proses pembelajaran kulikulum 2013 dihitung kurang melibatkan siswa dan harus beralih pada pada model pembelajaran yang lebih mengaktifkan siswa, sehingga siswa tidak cenderung pasif.

Berdasarkan kajian di atas terhadap hasil observasi, diperoleh permasalahan yang menjadi penyebab rendahnya keaktifan belajar siswa kelas XI Tata Kecantikan 3 SMK Negeri 2 Singaraja, yakni guru menggunakan metode yang kurang bervariasi dan siswa kurang dilibatkan secara aktif dalam kegiatan pembelajaran. Proses pembelajaran menyebabkan kurangnya keaktifan belajar siswa pada mata pelajaran Perawatan Wajah, Badan (Body Massage) dan Waxing pada kompetensi dasar membuat jamu dan boreh/lulur perawatan badan, sehingga mengakibatkan siswa cenderung menjadi pasif dalam belajar, kurang menghargai guru, dan kurang memahami materi yang disampaikan sehingga mempengaruhi hasil belajar siswa. Proses pembelajaran kurang efektif dan tujuan pembelajaran tidak tercapai seperti yang diharapkan jika penggunaan metode pembelajaran yang tidak bervariasi sehingga dapat mengakibatkan siswa merasa jenuh dan bosan.

Berdasarkan pada tanggapan beberapa siswa tentang metode ceramah yang digunakan guru dalam mengajar, mereka cenderung merasa jenuh dan bosan selama pembelajaran karena guru hanya berceramah dalam penyampaian materi. Oleh sebab itu, untuk menciptakan proses pembelajaran yang lebih efektif, meningkatkan interaksi yang terjadi pada siswa dan dapat meningkatkan keaktifan belajar siswa, maka perlu diterapkan metode mengajar yang bervariasi didalam proses pembelajaran. Kesenjangan antara kondisi harapan dengan kondisi nyata di lapangan akan tertulis dalam latar belakang masalah. Pada kondisi harapan ada banyak hal yang perlu mendapat perhatian seperti, kemampuan guru memahami model-model pembelajaran, kemampuan guru memahami metode, strategi, teknik serta pendekatan yang dilakukan dalam memberikan pembelajaran di kelas untuk memacu peningkatan mutu pendidikan agar sesuai harapan. 
Solusi untuk mengatasi permasalahan belajar siswa kelas XI Tata Kecantikan 3 SMK Negeri 2 Singaraja tersebut, adalah dengan menerapkan model pembelajaran berbasis proyek (project based learning). Alasan pemilihan pembelajaran berbasis proyek adalah karena dengan menggunakan model pembelajaran tersebut, selain dituntut aktif dalam pembuatan proyek, siswa juga dituntut untuk aktif dalam belajar sehingga materi yang dipelajari dapat terselesaikan sesuai dengan tujuan pembelajaran (Faizah, 2015; Hairunisa et al., 2019; Pratiwi \& Setyaningtyas, 2020).

Model pembelajaran Project based learning (PjBL) adalah model pembelajaran yang menuntut pengajar dan atau peserta didik mengembangkan pertanyaan penuntun (Afriana et al., 2016; Mustika \& Ain, 2020; Mutakinati et al., 2018). Mengingat bahwa masing-masing peserta didik memiliki gaya belajar yang berbeda, sehingga memberikan kesempatan kepada para peserta didik untuk menggali konten (materi) dengan menggunakan berbagai cara yang bermakna bagi dirinya, dan melakukan eksperimen secara kolaboratif serta merupakan pendekatan pembelajaran yang memperhatikan keaktifan peserta didik. Peserta didik melakukan eksplorasi, penilaian, interpretasi dan mensintesis informasi melalui cara yang bermakna.

Project based learning (PjBL) merupakan model pembelajaran yang pelaksanaan pembelajarannya berfokus pada masalah yang dipilih sehingga siswa tidak hanya mempelajari konsepkonsep yang berhubungan dengan masalah tetapi juga metode ilmiah dalam memecahkan masalah tersebut (Cahyaningsih et al., 2020; Suryandari et al., 2018; Wijanarko et al., 2017). Tujuannya untuk memperoleh kemampuan dan kecakapan kognitif dalam memecahkan masalah secara rasional, lugas, dan tuntas. Oleh sebab itu, siswa tidak hanya memahami konsep yang relevan dengan masalah yang menjadi pusat perhatian tetapi juga memperoleh pengalaman belajar yang berhubungan dengan keterampilan menerapkan metode ilmiah dalam pemecahan masalah dan menumbuhkan pola berfikir kritis (Hasanah et al., 2018; Rendra et al., 2018; Wajdi, 2017; Yuwono \& Syaifuddin, 2017).

Penelitian ini diperkuat oleh beberapa penelitian terdahulu yang relevan dengan penelitian ini yaitu, pertama penelitian yang dilakukan oleh (Kristiyanto, 2020), yang memperoleh hasil penelitian berupa penerapan model project based learning (PJBL) berpengaruh terhadap peningkatan kemampuan berpikir kritis dan hasil belajar matematika. Kedua, penelitian yang dilakukan oleh (Cahyaningsih et al., 2020), yang memperoleh hasil penelitian berupa model project based learning berbantu multimedia power point dinyatakan efektif terhadap hasil belajar IPA. Ketiga, penelitian yang dilakukan oleh (Mulyadi, 2015), yang memperoleh hasil penelitian berupa penerapan model project based learning untuk berpengaruh terhadap peningkatan kinerja dan prestasi belajar siswa.

Tujuan dari dilaksanakannya penelitian ini adalah untuk menganalisis penerapan model pembelajaran Project Based Learning (PjBL) untuk meningkatkan keaktifan dan hasil belajar siswa pada kompetensi dasar membuat jamu dan boreh/lulur perawatan badan kelas XI tata kecantikan 3 semester genap SMK Negeri 2 Singaraja tahun pelajaran 2019/2020.

\section{Metode}

Penelitian yang dilakukan ini termasuk penelitian tindakan kelas. Pelaksanaan penelitian direncanakan berlangsung dari bulan Januari sampai bulan April 2019 pada SMK Negeri 2 Singaraja. Penelitian ini dilaksanakan pada semester 2 (genap) tahun pelajaran 2019/2020. Subjek dalam penelitian ini adalah semua siswa kelas XI Tata Kecantikan 3 SMK Negeri 2 Singaraja sebanyak 33 siswa. Objek penelitian ini adalah peningkatan keaktifan belajar dan hasil belajar Membuat Jamu dan Boreh/Lulur Perawatan Badan siswa kelas XI Tata Kecantikan 3 SMK Negeri 2 Singaraja. Metode pengumpulan data yang digunakan pada penelitian ini adalah dengan memberikan instrumen yang digunakan untuk menilai keaktifan dan hasil belajar siswa. Instrumen yang digunakan untuk menilai keaktifan belajar dan hasil belajar siswa kelas XI Tata Kecantikan 3 adalah lembar observasi dan lembar penilaian hasil belajar. Lembar ini terlampir di setiap RPP pada lampiran, sebagai teknik pengumpulan data. Analisis data yang digunakan pada penelitian ini adalah analisis deskriptif kuantitatif. Teknik analisis data tersebut digunakan untuk menganalisis penerapan model pembelajaran Project Based Learning (PjBL) untuk meningkatkan keaktifan dan hasil belajar siswa pada kompetensi dasar membuat jamu dan boreh/lulur perawatan badan kelas XI tata kecantikan 3 semester genap SMK Negeri 2 Singaraja tahun pelajaran $2019 / 2020$.

\section{Hasil dan Pembahasan}

Hasil Penelitian dilaksanakan di SMK Negeri 2 Singaraja pada siswa kelas XI Tata Kecantikan 3 yang berjumlah 33 siswa. Kegiatan awal penelitian dilaksanakan dengan melakukan observasi keaktifan belajar siswa di dalam kelas selama kegiatan pembelajaran berlangsung dan wawancara dengan guru 
mata pelajaran Perawatan Wajah, Badan (Body Massage) dan Waxing pada kompetensi dasar Membuat Jamu dan Boreh/Lulur Perawatan Badan dan beberapa siswa kelas XI Tata Kecantikan 3 yang dipilih secara acak dan dianggap mewakili untuk mengetahui kondisi awal kelas XI Tata Kecantikan 3 berkaitan dengan pembelajaran Membuat Jamu dan Boreh/Lulur Perawatan Badan di kelas.

Penelitian Tindakan Kelas di kelas XI Tata Kecantikan 3 SMK Negeri 2 Singaraja dilakukan berdasarkan hasil observasi awal yang diketahui bahwa keaktifan belajar Membuat Jamu dan Boreh/Lulur Perawatan Badan siswa di dalam kelas masih rendah. Berdasarkan pengamatan pada saat kegiatan pembelajaran berlangsung dan hasil wawancara dengan beberapa siswa, permasalahan tersebut muncul dikarenakan guru menggunakan metode yang kurang bervariasi yakni hanya dengan berceramah dan praktek, siswa kurang dilibatkan secara aktif dalam kegiatan pembelajaran. Proses pembelajaran menyebabkan kurangnya keaktifan belajar siswa pada pelajaran Membuat Jamu dan Boreh/Lulur Perawatan Badan sehingga mengakibatkan siswa cenderung menjadi pasif dalam belajar, kurang menghargai guru dan teman, dan kurang memahami materi yang disampaikan.

Guru sebagai pendidik dituntut untuk mengembangkan potensinya, salah satunya yakni dengan menerapkan metode pembelajaran yang inovatif dan kreatif sehingga keaktifan belajar siswa dapat meningkat. Salah satu upaya untuk meningkatkan keaktifan belajar siswa di kelas adalah dengan melakukan perbaikan dalam proses pembelajaran. Model pembelajaran project based learning (PjBL) merupakan salah satu model pembelajaran yang menuntut siswa untuk aktif dan saling membantu dalam membuat proyek yang sedang dibahas yaitu dengan cara diskusi dan bekerjasama. Dari hasil pengamatan keaktifan belajar, semua aspek atau indikator keaktifan belajar siswa telah mencapai baseline keberhasilan pembelajaran pada masing- masing siklus.

Berdasarkan hasil penelitian ini menunjukkan bahwa penerapan model pembelajaran project based learning (PjBL) memiliki dampak positif dalam meningkatkan keaktifan belajar siswa. Hal ini dapat dilihat dari semakin aktifnya siswa dalam mengkituki pembelajaran yang disampaikan guru, sehingga keaktifan belajar siswa meningkat yaitu: $61,69 \%$, menjadi $81,82 \%$. Itu artinya terdapat peningkatan sebesar 20,13\% Dan pada siklus II keaktifan belajar siswa telah tercapai.

Hasil penelitian selanjutnya dalam penelitian ini menunjukkan bahwa penerapan model pembelajaran project based learning (PjBL) memiliki dampak positif dalam meningkatkan hasil belajar siswa. Hal ini dapat dilihat dari semakin mantapnya pemahaman siswa terhadap materi yang disampaikan guru sehingga hasil belajar meningkat yaitu: 79,77\%; menjadi 82,27\% Pada siklus II hasil belajar siswa telah tercapai. Maka dapat disimpulkan maka keaktifan belajar dan hasil belajar siswa untuk pelajaran membuat jamu dan boreh/lulur perawatan badan dengan menerapkan model pembelajaran project based learning (PjBL) hasilnya baik.

Model pembelajaran Project based learning (PjBL) adalah model pembelajaran yang menuntut pengajar dan atau peserta didik mengembangkan pertanyaan penuntun (Afriana et al., 2016; Mustika \& Ain, 2020; Mutakinati et al., 2018). Mengingat bahwa masing-masing peserta didik memiliki gaya belajar yang berbeda, sehingga memberikan kesempatan kepada para peserta didik untuk menggali konten (materi) dengan menggunakan berbagai cara yang bermakna bagi dirinya, dan melakukan eksperimen secara kolaboratif serta merupakan pendekatan pembelajaran yang memperhatikan keaktifan peserta didik. Peserta didik melakukan eksplorasi, penilaian, interpretasi dan mensintesis informasi melalui cara yang bermakna.

Project based learning (PjBL) merupakan model pembelajaran yang pelaksanaan pembelajarannya berfokus pada masalah yang dipilih sehingga siswa tidak hanya mempelajari konsepkonsep yang berhubungan dengan masalah tetapi juga metode ilmiah dalam memecahkan masalah tersebut (Cahyaningsih et al., 2020; Suryandari et al., 2018; Wijanarko et al., 2017). Tujuannya untuk memperoleh kemampuan dan kecakapan kognitif dalam memecahkan masalah secara rasional, lugas, dan tuntas. Oleh sebab itu, siswa tidak hanya memahami konsep yang relevan dengan masalah yang menjadi pusat perhatian tetapi juga memperoleh pengalaman belajar yang berhubungan dengan keterampilan menerapkan metode ilmiah dalam pemecahan masalah dan menumbuhkan pola berfikir kritis (Hasanah et al., 2018; Rendra et al., 2018; Wajdi, 2017; Yuwono \& Syaifuddin, 2017).

Penelitia ini diperkuat oleh beberapa penelitian terdahulu yang relevan dengan penelitian ini yaitu, pertama penelitian yang dilakukan oleh (Kristiyanto, 2020), yang memperoleh hasil penelitian berupa penerapan model project based learning (PJBL) berpengaruh terhadap peningkatan kemampuan berpikir kritis dan hasil belajar matematika. Kedua, penelitian yang dilakukan oleh (Cahyaningsih et al., 2020), yang memperoleh hasil penelitian berupa model project based learning berbantu multimedia power point dinyatakan efektif terhadap hasil belajar IPA. Ketiga, penelitian yang dilakukan oleh (Mulyadi, 2015), yang memperoleh hasil penelitian berupa penerapan model project based learning untuk berpengaruh terhadap peningkatan kinerja dan prestasi belajar siswa. 
Implikasi penelitian tindakan kelas mengenai penerapan model pembelajaran project-based learning (PjBL) ini adalah memperoleh pengalaman belajar yang berhubungan dengan keterampilan menerapkan metode ilmiah dalam pemecahan masalah dan menumbuhkan pola berfikir kritis bagi siswa.

\section{Simpulan}

Berdasarkan hasil penelitian tindakan kelas yang telah dilaksanakan dalam 2 (dua) siklus pada penelitian ini, dapat disimpulkan bahwa penerapan model pembelajaran project based learning (PjBL) dapat meningkatkan keaktifan dan hasil belajar membuat jamu dan boreh/lulur perawatan badan siswa kelas XI tata kecantikan 3 semester genap SMK Negeri 2 Singaraja tahun pelajaran 2019/2020. Implikasi penelitian ini adalah memperoleh pengalaman belajar yang berhubungan dengan keterampilan menerapkan metode ilmiah dalam pemecahan masalah dan menumbuhkan pola berfikir kritis bagi siswa.

\section{Daftar Rujukan}

Afriana, J., Permanasari, A., \& Fitriani, A. (2016). Penerapan project based learning terintegrasi STEM untuk meningkatkan literasi sains siswa ditinjau dari gender. Jurnal Inovasi Pendidikan IPA, 2(2), 202. https://doi.org/10.21831/jipi.v2i2.8561

Amelia, D. J., \& Saputra, S. Y. (2017). Analisis Kelayakan Buku Siswa Kelas IV Tema Makhluk Hidup Kurikulum 2013. Pedagogia: Jurnal Pendidikan, 6(1), 98-109. https://doi.org/10.21070/pedagogia.v6i1.617

Cahyaningsih, R. N., Siswanto, J., \& Sukamto. (2020). Keefektifan Model Project Based Learning Berbantu Multimedia Power Point Terhadap Hasil Belajar IPA. Jurnal Penelitian Dan Pengembangan Pendidikan, 4(1), 34-40. https://doi.org/10.23887/jppp.v4i1.25014

Edriati, S., Hamdunah, H., \& Astuti, R. (2016). Peningkatan Prestasi Belajar Matematika Siswa SMK Melalui Model Quantum Teaching Melibatkan Multiple Intelligence. Cakrawala Pendidikan: Jurnal Ilmiah Pendidikan, 35(3). https://doi.org/10.21831/cp.v35i3.8253

Faizah, U. (2015). Penerapan Pendekatan Saintifik Melalui Model Project Based Learning Untuk Meningkatkan Ketrampilan Proses Dan Hasil Belajar Siswa Kelas IV SD Negeri Seworan, Wonosegoro. Scholaria: Jurnal Pendidikan Dan Kebudayaan, 5(1), 24-38. https://doi.org/10.24246/j.scholaria.2015.v5.i1.p24-38

Fitriyadi, H. (2013). Keterampilan TIK Guru Produktif SMK di Kabupaten Hulu Sungai Utara dan Implementasinya dalam Pembelajaran. Jurnal Pendidikan Vokasi, 2(2), 213-233. https://doi.org/10.21831/jpv.v2i2.1033

Hairunisa, Arif Rahman Hakim, \& Nurjumiati. (2019). Studi Pengaruh Model Pembelajaran Berbasis Proyek (Project Based Learning) Terhadap Kreativitas Mahasiswa Program Studi PGSD Pada Mata Kuliah Konsep Dasar IPA. Jurnal Pendidikan Mipa, 9(2), 93-96. https://doi.org/10.37630/jpm.v9i2.190

Hasanah, I., Sarwanto, S., \& Masykuri, M. (2018). Pengembangan Modul Suhu dan Kalor Berbasis Project Based Learning untuk Meningkatkan Keterampilan Proses Sains dan Kemampuan Berpikir Kritis Siswa SMA/MA. Jurnal Pendidikan (Teori Dan Praktik), 3(1), 38-44. https://doi.org/10.26740/jp.v3n1.p38-44

Indriani, A. (2015). Penerapan Pembelajaran Tematik Kurikulum 2013 oleh Guru SD/MI di Desa Klepek Kecamatan Sukosewu Kabupaten Bojonegoro Semester Gasal Tahun Ajaran 2014/2015. Jurnal VARIDIKA, 27(1), 43-49. https://doi.org/10.23917/varidika.v27i1.738

Indriyani, V., Zaim, M., Atmazaki, A., \& Ramadhan, S. (2019). Literasi Baca Tulis Dan Inovasi Kurikulum Bahasa. KEMBARA: Jurnal Keilmuan Bahasa, Sastra, Dan Pengajarannya, 5(1), 108. https://doi.org/10.22219/kembara.vol5.no1.108-118

Krissandi, A. D. S., \& Rusmawan, R. (2015). Kendala Guru Sekolah Dasar Dalam Implementasi Kurikulum 2013. Jurnal Cakrawala Pendidikan, 3(3), 457-467. https://doi.org/10.21831/cp.v3i3.7409

Kristiyanto, D. (2020). Peningkatan Kemampuan Berpikir Kritis dan Hasil Belajar Matematika dengan Model Project Based Learning (PJBL). Mimbar Ilmu, 25(1), 1-10. https://doi.org/10.23887/mi.v25i1.24468

Kurniaman, O., \& Noviana, E. (2017). Penerapan Kurikulum 2013 Dalam Meningkatkan Keterampilan, Sikap, Dan Pengetahuan. Primary: Jurnal Pendidikan Guru Sekolah Dasar, 6(2), 389. https://doi.org/10.33578/jpfkip.v6i2.4520 
Kurniasari, F. (2017). Implementasi Pendekatan Saintifik Pada Penugasan Aktivitas Di Buku Teks Bahasa Indonesia Kelas VII SMP Berdasarkan Kurikulum 2013. Jurnal Pendidikan Edutama, 4(1), 9-26. https://doi.org/10.30734/jpe.v4i1.44

Morelent, Y., \& Syofiani. (2018). Pengaruh Penerapan Kurikulum 2013 Terhadap Pembentukan Karakter Siswa Sekolah Dasar Negeri 05 Percobaan Pintu Kabun Bukittinggi. Jurnal Penelitian Bahasa Dan Sastra Indonesia, 1(2), 141-152. https://doi.org/10.22202/jg.2015.v1i2.1234

Mulyadi, E. (2015). Penerapan Model Project Based Learning untuk Meningkatan Kinerja dan Prestasi Belajar Fisika Siswa SMK. Jurnal Pendidikan Teknologi Dan Kejuruan, 22(4), 385-395. https://doi.org/10.21831/jptk.v22i4.7836

Mulyadin. (2016). Implementasi Kebijakan Pembelajaran Tematik Terpadu Kurikulum 2013 Di SDN Kauman 1 Malang Dan SD Muhammadiyah 1 Malang. Jurnal Edutama, 3(2), 31-48. https://doi.org/10.30734/jpe.v3i2.35

Mustika, D., \& Ain, S. Q. (2020). Peningkatan Kreativitas Mahasiswa Menggunakan Model Project Based Learning dalam Pembuatan Media IPA berbentuk Pop Up Book. Jurnal Basicedu, 4(4), 1167-1175. https://doi.org/10.31004/basicedu.v4i4.518

Mutakinati, L., Anwari, I., \& Yoshisuke, K. (2018). Analysis of students' critical thinking skill of middle school through stem education project-based learning. Jurnal Pendidikan IPA Indonesia, 7(1), 5465. https://doi.org/10.15294/jpii.v7i1.10495

Pratiwi, E. T., \& Setyaningtyas, E. W. (2020). Kemampuan Berpikir Kritis Siswa SD dengan Model Pembelajaran Problem Based Learning dan Model Pembelajaran Project Based Learning. Jurnal Basicedu, 4(2), 379-388. https://doi.org/10.31004/basicedu.v4i4.445

Rendra, G. R. P., Darmawiguna, I. G. M., \& Sindu, I. G. P. (2018). Pengembangan e-modul berbasis project based learning menggunakan schoology (Studi Kasus Mata Pelajaran Web Design Kelas XI Multimedia Di SMK TI Bali Global Singaraja). Karmapati, 7(2), 50-58. https://doi.org/10.23887/karmapati.v7i2.15269

Resbiantoro, G. (2016). Analisis Pedagogical Content Knowledge (Pck) Terhadap Buku Guru Sd Kurikulum 2013. Scholaria: Jurnal Pendidikan Dan Kebudayaan, 6(3), 153. https://doi.org/10.24246/j.scholaria.2016.v6.i3.p153-162

Said, I. M., Sutadji, E., \& Sugandi, M. (2019). Pengembangan Bahan Ajar Berbasis Cooperative Learning Dengan Pendekatan Saintifik Untuk Siswa Smk Se-Kota Malang Program Keahlian Teknik Ototronik. Jurnal Pendidikan: Teori, Penelitian Dan Pengembangan, 1(2), 265-270. https://doi.org/10.17977/jp.v1i2.6131

Shafa. (2014). Karakteristik Proses Pembelajaran Kurikulum 2013. Jurnal Dinamika Ilmu, 14(1), 81-96. https://doi.org/10.21093/di.v14i1.9

Sugiyanto, S., Kartowagiran, B., \& Jailani, J. (2015). Pengembangan Model Evaluasi Proses Pembelajaran Matematika Di SMP Berdasarkan Kurikulum 2013. Jurnal Penelitian Dan Evaluasi Pendidikan, 19(1), 82-95. https://doi.org/10.21831/pep.v19i1.4558

Suryandari, K. C., Sajidan, Rahardjo, S. B., Prasetyo, Z. K., \& Fatimah, S. (2018). Project-Based Science Learning And Pre-Service Teachers' Science Literacy Skill And Creative Thinking. Cakrawala Pendidikan, 27(3), 345-355. https://doi.org/https://doi.org/10.21831/cp.v38i3.17229

Wahyudin, W. (2018). Optimalisasi Peran Kepala Sekolah dalam Implementasi Kurikulum 2013. Jurnal Kependidikan, 6(2), 249-265. https://doi.org/10.24090/jk.v6i2.1932

Wajdi, F. (2017). Implementasi Project Based Learning (PBL) Dan Penilaian Autentik Dalam Pembelajaran Drama Indonesia. Jurnal Pendidikan Bahasa Dan Sastra, 17(1), 81-97. https://doi.org/10.17509/bs_jpbsp.v17i1.6960

Wijanarko, A. G., Supardi, K. I., \& Marwoto, P. (2017). Keefektifan Model Project Based Learning Terbimbing untuk Meningkatkan Keterampilan Proses Sains dan Hasil Belajar IPA. Journal of Primary Education, 6(2), 120-125. https://doi.org/10.15294/jpe.v6i2.17561

Yuwono, M. R., \& Syaifuddin, M. W. (2017). Pengembangan problem based learning dengan assessment for learning berbantuan smartphone dalam pembelajaran matematika. Beta Jurnal Tadris Matematika, 10(2), 184-202. https://doi.org/10.20414/betajtm.v10i2.116 